\title{
Nanostructured Pt-Ru / Ionic Liquid Crystal Composite for Electrocatalytic Oxidation of Methanol
}

\author{
Mohammad H. BinSabt ${ }^{1}$, Nada F. Atta ${ }^{2, *}$, Yousef M. Ahmed ${ }^{2}$, Ahmed Galal $^{2}$ \\ ${ }^{1}$ Chemistry Department, Faculty of Science, Kuwait University, 13060-Safat, Kuwait \\ ${ }^{2}$ Chemistry Department, Faculty of Science, Cairo University, Giza 12613, Egypt \\ *E-mail: anada@sci.cu.edu.eg
}

doi: $10.20964 / 2017.12 .03$

Received: 8 August 2017 / Accepted: 22 September 2017 / Published: 12 November 2017

In this work, we report a highly active and durable methanol oxidation electrocatalyst, for the first time, based on the synergy of platinum-ruthenium-ionic liquid crystal (Pt-Ru-ILC). The incorporation of ionic liquid crystal played a main role resulting in quite uniform and ordered surface arrays. The ILC allowed more available catalytic sites while providing high ionic conductance surface. The efficiency of methanol oxidation increases while realizing the removal of carbonaceous poisoning products from the catalyst surface. The crystalline nature of piperidinium ILC resulted in the nucleation of nano-catalyst with an average size of $3 \mathrm{~nm}$. Compared to other nano-catalysts, Pt-Ru-ILC displayed an $\mathrm{I}_{\mathrm{F}} / \mathrm{I}_{\mathrm{R}}$ ratio of 12.2 with relatively higher current densities and lower methanol oxidation potential. A promising long-term durability and stability were also realized by the present catalyst.

Keywords: Methanol fuel cell; Ionic liquid crystals; Pt-Ru nanoparticles; Carbonaceous poison; Electrocatalyst.

\section{FULL TEXT}

(C) 2017 The Authors. Published by ESG (www.electrochemsci.org). This article is an open access article distributed under the terms and conditions of the Creative Commons Attribution license (http://creativecommons.org/licenses/by/4.0/). 